\title{
A Novel Approach for Adsorption of Copper(II) Ions from Wastewater Using Cane Papyrus
}

\author{
Mohammed Jaafar Ali Al-atabe ${ }^{1}$
}

Department of Environmental Engineering, Al-Mustansaryah University, Baghdad, IRAQ

Received 20 December 2017; accepted 30 March 2018, available online 01 May 2018

\begin{abstract}
This study tested the suitability of Cane Papyrus as a biological sorbent for the removal of $\mathrm{Cu}^{2+}$ ions from wastewater. Fourier transform infra-red analysis for the Cane Papyrus confirmed the presence of amino ($\mathrm{NH})$, carbonyl $(-\mathrm{C}=\mathrm{O})$ and hydroxyl $(-\mathrm{OH})$ functional groups. Bath mode was used, and the effects of the following parameters were investigated: adsorbent dosage (from 10 to 50 ) $\mathrm{g} / \mathrm{l}, \mathrm{pH}$ values, $\mathrm{Cu}^{2+}$ initial concentration and contact time. The results revealed a higher efficiency $(95 \%)$ of powdered adsorbent for $\mathrm{Cu}^{2+}$ ions removal. This highest adsorption efficiency was found to occur at $\mathrm{pH} 6.5$ with $50 \mathrm{~g} / \mathrm{l}$ Cane Papyrus and $2 \mathrm{hr}$ experimental duration. The Freundlich isotherm model more suitably described the adsorption process than the langmuir model with linearized coefficients of 0.95 and 0.844 respectively. Pseudo-second order kinetic equation best described the kinetics of the reaction. Furthermore, $0.5 \mathrm{M} \mathrm{HCl}$ was a better desorbing agent than $0.5 \mathrm{M} \mathrm{NaOH}$ and de-ionized water. The experimental data obtained demonstrated that Cane Papyrus can be used as a suitable adsorbent for Copper(II) ion removal from wastewater.
\end{abstract}

Keywords: Adsorption, Cane Papyrus, Copper(II) ions, Kinetics, Removal Efficiency

\section{Introduction}

Heavy metal pollution has been one of the most challenging environmental problems due to their toxicity, persistence and bioaccumulation tendencies [1]. Most industries produce and discharge metal-containing wastes mostly into water bodies, which affect the aesthetic quality of the water and increase the concentrations of metals present [2]. Activities such as mining and smelting operations, wastewater treatment facilities, various agricultural works and metal castings contribute significantly to the concentration of heavy metals in the environment [3]. Heavy metal contamination is not a recent problem, but its management and prevention are still of global concern. Examples of involved heavy metal ions include $\mathrm{Cd}^{2+}, \mathrm{Cr}^{6+}, \mathrm{Cu}^{2+}, \mathrm{Hg}^{2+}, \mathrm{Ni}^{2+}$ and $\mathrm{Pb}^{2+}$. Elevated concentrations of heavy metals are toxic for living organisms. For example, high concentrations of $\mathrm{Cu}^{2+}$ can cause diseases such as deformation of bones, extra cholesterol intake, and anemia. The allowable amount of copper is $2 \mathrm{mg} / \mathrm{L}$, according to the European Union standards [4].

Several techniques have been designed for heavy metals removal from aqueous solutions and these include ion exchange, chemical precipitation/co-precipitation, filtration, coagulation, membrane technologies and commercial activated carbon. The major disadvantages of these methods lie in the cost involved, the efficiency of the processes and disposal of wastes generated [5]. Technologies to treat $\mathrm{Cu}^{2+}$ contaminated waters include (i) adsorption both in batch and column operations [6], (ii) coagulation, electro coagulation and flocculation, (iii) ion exchange, and (iv) membrane filtration [7]. Convenient designing and operation made adsorption in packed beds the most applicable practice among these technologies, in a frugal approach [8]. Adsorption processes can eliminate many contaminants in a multibarrier approach. There is a growing interest in the application of plant biomass for water treatment in general and aqueous $\mathrm{Cu}^{2+}$ removal. The main advantage of plant biomass is that they are readily available and can work under near neutral $\mathrm{pH}$. The contaminant removal mechanism by this class of material is not established. It is currently understood that the driving force for decontamination relies in its affinity to several species present in the biomass structure (e.g. $\mathrm{Ca}^{2+}, \mathrm{Mg}^{2+}, \mathrm{OH}^{-}$and $-\mathrm{NH}_{2}$, cellulosic groups). Relevant removal mechanisms include bio sorption, ion-exchange and physical adsorption [9]. In recent years, several plant materials have been positively tested for $\mathrm{Cu}^{2+}$ removal including (i) cinnamomum camphora [10] and (ii) modified barley straw [11]. A literature reviews indicates that Cane Papyrus hasn't yet been used for $\mathrm{Cu}^{+2}$ removal from industrial waste water.

This study presents the use of Cane Papyrus as a potential, novel, environmentally friendly and lowcost adsorbent for the remediation of $\mathrm{Cu}^{+2}$ ions from aqueous solution and wastewater samples. The objective of the present study is to investigate the adsorption potential of Cane Papyrus in the removal of $\mathrm{Cu}^{+2}$ ions from aqueous 
solution. The effects of $\mathrm{pH}$, adsorbent amount, contact time and concentration of metal ions in the solution. The langmuir and Freundlich isotherms models are used to investigate equilibrium data. The adsorption mechanisms of $\mathrm{Cu}^{+2}$ ions onto Cane Papyrus are also evaluated in terms of kinetics and thermodynamics.

\section{Experimental Section}

Preparation of adsorbent Cane Papyrus was collected from farmlands in the marshes of Messan, south of Iraq. The leaves were carefully detached from the stem of the plant and washed thoroughly with tap water to remove dirt, soil particles and debris and subsequently sun dried for 10 days. The dry biomass was ground to fine powder using a hammer mill and weighed. The resulting powder was fractionated using analytical sieves. Particles of $10-$ $200 \mu \mathrm{m}$ were used for simulated wastewater samples. The adsorbent showed a fluffy and highly porous and rough microstructure containing some voids and cracks which is suitable for the adsorption of $\mathrm{Cu}^{+2}$ ions. The concentration of $\mathrm{Cu}^{+2}$ ions in aqueous solution was analyzed using Atomic Absorption Spectrometer (AAS). Mechanical shaker with adjustable speed, time was used for agitation and $\mathrm{pH}$ meter was used for all $\mathrm{pH}$ measurements.

One gram of powdered Cane Papyrus was used for the adsorption of $\mathrm{Cu}^{+2}$ ions onto the surface of Cane Papyrus using mechanical shaker with the speed of 200 $\mathrm{rpm}$ at $25 \mathrm{C}^{\circ}$. The effect of adsorbent dosage was investigated by varying the initial mass of the adsorbent between (5-100) gm. The optimum dosage obtained was used for subsequent processes. Similarly, the effects of $\mathrm{pH}$, initial $\mathrm{Cu}^{2+}$ removal was initiated by contacting 0.0 to $5.0 \mathrm{~g}$ of the adsorbent with a $100 \mathrm{ml} \mathrm{Cu}^{2+}$ solution in a closed cylindrical plastic vessel of $250 \mathrm{ml}$ volume. and 5$120 \mathrm{~min}$, respectively.

Copper sulfate $\left(\mathrm{CuSO}_{4} .5 \mathrm{H}_{2} \mathrm{O}\right)$ was used as the source of $\mathrm{Cu}^{2+}$ ion in a simulated effluent solution. The solution was made from water with total dissolved solids (TDS) $\mathrm{f}$ $200 \mathrm{mg} / \mathrm{l}$ and $\mathrm{pH}$ value of 7. Hydrochloric acid and sodium hydroxide solutions with $1 \mathrm{M}$ concentration were used to adjust the $\mathrm{pH}$ value. Solution samples were prepared with the following contaminant concentrations of $2.0,3.0$ and $4.5 \mathrm{mg} / \mathrm{L}$. After equilibration for $60 \mathrm{~min}$, the adsorbent was recovered. Residual $\mathrm{Cu}^{+2}$ ions on the surface of the used adsorbent was removed by washing it three times with ultra-pure water. De-ionized water, $1 \mathrm{M}$ $\mathrm{NaOH}$ and $1 \mathrm{M} \mathrm{HCl}$ were tested as potential desorbing agents. $40 \mathrm{ml}$ of the desorbing agents were introduced into a $100 \mathrm{ml}$ Teflon container containing the recovered adsorbent and equilibrated for $60 \mathrm{~min}$ at a speed of 200 $\mathrm{rpm}$ and $\mathrm{T}=25 \mathrm{C}^{\circ}$. The aqueous solutions after equilibration were centrifuged and the supernatant were analyzed to determine the concentration of $\mathrm{Cu}^{+2}$ ions after desorption.

\section{Results and Discussion}

\subsection{Infra-Red Spectroscopy Results}

The results from the Fourier transform infra-red showed a broad peak at $3000 \mathrm{~cm}^{-1}$ with a high transmittance frequency, which can be attributed to either $-\mathrm{OH}$ or $-\mathrm{NH}$ groups. As shown in Fig. 1, the band observed at $2550 \mathrm{~cm}^{-1}$ is possibly due to $\mathrm{C}-\mathrm{H}$ stretching vibrations of saturated aliphatic compounds as reported by Smith while the band at $1750 \mathrm{~cm}^{-1}$ can be attributed to $-\mathrm{NH}$ bending vibration of primary amines. A small peak was observed at $1350 \mathrm{~cm}^{-1}$ and corresponds to $\mathrm{v}(\mathrm{C}-\mathrm{C})$ stretching vibrations of aromatic rings. The peaks observed at $1200 \mathrm{~cm}^{-1}$ and $1150 \mathrm{~cm}^{-1}$ corresponds to the $\mathrm{C}$ $\mathrm{O}$ stretch of alcohols, carboxylic acids, esters or ethers. The absorption band at $500 \mathrm{~cm}^{-1}$ can be due to the presence of an alkyl halide. Also confirmed that mucilage extracted from Diceriocaryum species contains carboxyl functional group. The presence of acidic functional groups is responsible for its adsorptive property. The stated clearly from their studies of natural plant materials that the biochemical characteristics of acidic functional groups are responsible for their metal ion uptake [12].

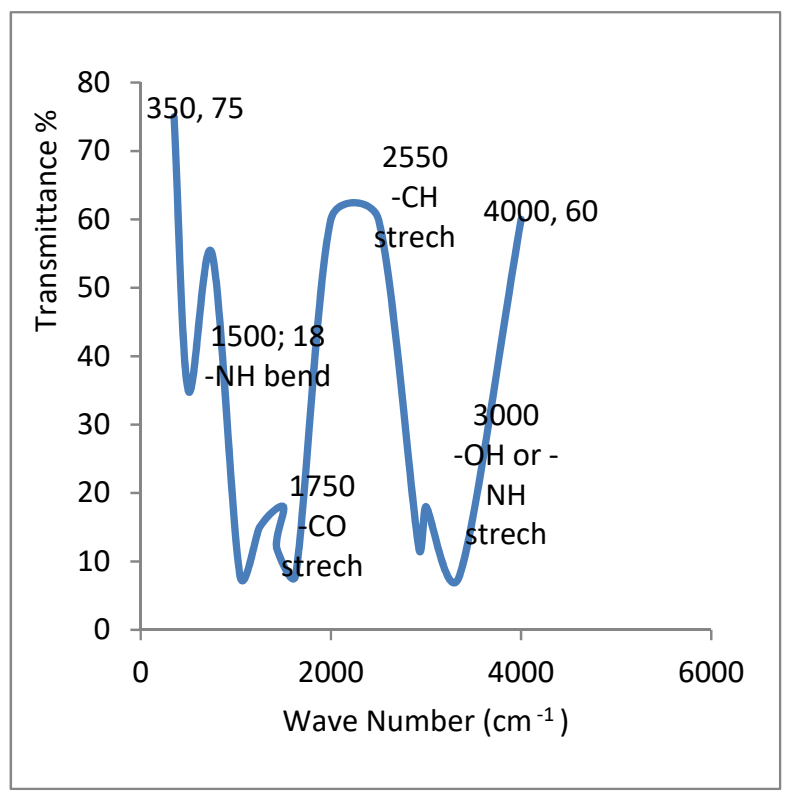

Fig.1 Infra-red spectra of the Cane Papyrus.

The chemical composition of the adsorbent was analyzed using X-ray Fluorescence spectrometer. The chemical composition of the adsorbent is presented in Table 1.

Table 1. Chemical Composition of Cane Papyrus.

\begin{tabular}{llll} 
Compound & Wt $\%$ & Compound & Wt \% \\
$\mathrm{Na}_{2} \mathrm{O}$ & 1.17 & $\mathrm{~K}_{2} \mathrm{O}$ & 11.7 \\
$\mathrm{MgO}$ & 6.93 & $\mathrm{CaO}$ & 23.9 \\
$\mathrm{Al}_{2} \mathrm{O}_{3}$ & 6.15 & $\mathrm{SiO}_{2}$ & 23.6 \\
$\mathrm{TiO}_{2}$ & 1.33 & $\mathrm{P}_{2} \mathrm{O}_{5}$ & 2.42 \\
$\mathrm{MnO}$ & 0.778 & $\mathrm{Fe}_{2} \mathrm{O}_{3}$ & 12.8 \\
$\mathrm{SO}_{3}$ & 5.68 & $\mathrm{SrO}$ & 1.24 \\
$\mathrm{Cl}$ & 1.09 & $\mathrm{BaO}$ & 0.521 \\
\hline
\end{tabular}

Table 2 show the Surface area of the adsorbent was $1.96 \mathrm{~m}^{2} / \mathrm{g}$. The average pore diameter of Cane Papyrus was within the range of $10<\mathrm{d}<1000 \times 10^{-8} \mathrm{~cm}$ and the 
adsorbent was classified as a meso porous material" . Similarly, reported BET surface areas of $1.083 \mathrm{~m}^{2} / \mathrm{g}$ and $2.52 \mathrm{~m}^{2} / \mathrm{g}$ for activated carbon from macadamia nuts used for phenol removal and maize tassels for heavy metal removal from polluted waters, respectively although adsorbents with higher surface areas have been widely reported in literature [13].

Table 2: Characteristics of Cane Papyrus.

\begin{tabular}{ll} 
Physical Parameters & Result \\
BET surface area $\left(\mathrm{m}^{2} / \mathrm{g}\right)$ & 1.96 \\
Micropore surface area $\left(\mathrm{m}^{2} / \mathrm{g}\right)$ & 1.75 \\
Total pore volume $\left(\mathrm{cm}^{3} / \mathrm{g}\right)$ & 0.01 \\
Micropore volume $\left(\mathrm{cm}^{3} / \mathrm{g}\right)$ & 0.0095 \\
Average pore diameter $\left(\right.$ Ao or $\left.10^{-8} \mathrm{~cm}\right)$ & 500 \\
\hline
\end{tabular}

The percentage removal of $\mathrm{Cu}^{+2}$ ions from aqueous solution was estimated by using Equation (1):

$\operatorname{Adsorption}(\%)=\frac{[\mathrm{Ci}-\mathrm{Cf}]}{\mathrm{Ci}} \times 100$

where $C_{i}$ and $C_{f}$ are the initial and final metal ion concentrations, respectively.

$\mathrm{qe}=\frac{(\mathrm{Co}-\mathrm{Ce}) \mathrm{V}}{\mathrm{w}}$

The equation 2 show that, qe is the amount of metal adsorbed in $\mathrm{mg} / \mathrm{g}, \mathrm{C}_{\mathrm{i}}$ and $\mathrm{C}_{\mathrm{e}}$ represent initial and equilibrium concentrations of metal ions in aqueous phase. $\mathrm{V}$ is the volume of the solution in liters (1) and W is the weight of the adsorbent used in grams".

\subsection{Effect of $\mathbf{p H}$}

Effect of $\mathrm{pH}$ on the variation of adsorption on the time of contact is presented in Fig. 2 at the experimental work conditions:50g adsorbent dosage; volume $=1 \mathrm{~L}$; $\left[\mathrm{Cu}^{2+}\right]$ concentration $=3 \mathrm{mg} / \mathrm{l}$. The initial $\mathrm{pH}$ of the solution was 8 . Another two $\mathrm{pH}$ values, i.e. 6.5 and 3, were also investigated. The best result was achieved for the solution with the $\mathrm{pH}$ value of 6.5 . More alkaline solutions with $\mathrm{pH}$ values higher than 8 were not investigated because metallic hydroxide (e.g. $\left.\mathrm{Cu}(\mathrm{OH})_{2}\right)$ could be formed at high $\mathrm{pH}$ values in the alkaline range. $\mathrm{Cu}^{2+}$ ions was precipitated as $\mathrm{Cu}(\mathrm{OH})_{2}$ that would be difficult to segregate from adsorbed and bio-adsorbed $\mathrm{Cu}^{2+}$. In essence $\mathrm{Cu}^{2+}$ ions can be present as $\mathrm{Cu}^{+}$as well but $\mathrm{Cu}^{+}$is not stable under atmospheric conditions. Since the aim of the present work was to investigate removal of the $\mathrm{Cu}^{2+}$ ions from the effluent solutions by using Cane Papyrus, $\mathrm{pH}$ values were kept to lower than 8 .

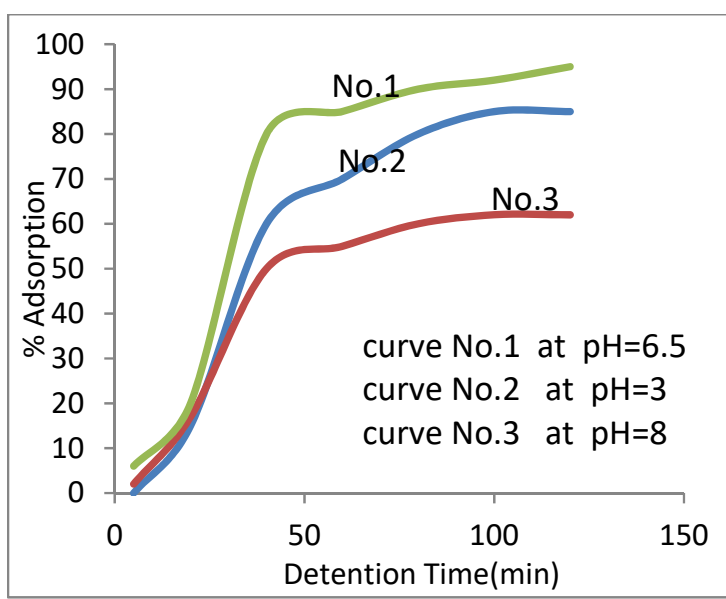

Fig. 2 pH values Effect on $\mathrm{Cu} 2+$ ions adsorption (\%) using Cane Papyrus.

Curve No.1 corresponds to 120 minutes and $95 \%$ $\mathrm{Cu}^{2+}$ ions removal. Curve No.2 corresponds to 120 minutes and $85 \% \mathrm{Cu}^{2+}$ removal. Curve No.3 corresponds to 120 minutes and $62 \% \mathrm{Cu}^{2+}$ ions removal the lines are not fitting functions, they simply connect points to facilitate visualization. The increase in $\mathrm{Cu}^{2+}$ ions removal with increase in $\mathrm{pH}$ values can be explained on the basis of a decrease in competition between proton and the metal cat-ions for reactions with the same functional groups. Another parameter is the decrease in positive charge of the adsorbent which results in a lower electrostatic repulsion between the metal cat-ions and the surface. Carboxyl and sulfate groups have been identified as the main sites for attachment of metal ions with the main chemicals in seaweed and, as these groups can have acidic property, their presence is $\mathrm{pH}$ dependent. These groups generate a negatively charged surface at the $\mathrm{pH}$ range of 3.5-5.0 and electrostatic interactions between cationic species and this surface is responsible for metal uptake. As the $\mathrm{pH}$ increased, the ligands such as carboxylate groups in Sargassum sp. would be exposed, increasing the negative charge density on the biomass surface, enhancing the attraction of metallic ions with positive charge and allowing the bio sorption onto the cell surface. With increasing $\mathrm{pH}$, the rate of adsorption also increases with the optimum $\mathrm{pH}$ of 4 for copper bio sorption. Copper ion forms an insoluble hydroxide which is precipitated at $\mathrm{pH}$ values higher than 4 and consequently no adsorption takes place. It is obvious that metal adsorption depends on the nature of the adsorbent surface. At low $\mathrm{pH}$, the $\mathrm{H}^{+}$ions compete with metal ions for the exchange sites in the system, thereby partially release metal ions. The heavy metals are completely released at very low $\mathrm{pH}$ values. The minimum amount of adsorption takes place at $\mathrm{pH} 2$ and then increases with decreasing acidity of the solution. The minimum adsorption at low $\mathrm{pH} \leq 2$ may be due to higher concentration and higher mobility of $\mathrm{H}^{+}$ions which are preferentially adsorbed over metal ions. 


\subsection{Effect of the initial $\mathrm{Cu}^{+2}$ ion Concentration}

Fig. 3 shows, the adsorption rate increased with increasing concentration of $\mathrm{Cu}^{2+}$ ions. A higher aqueous concentration of $\mathrm{Cu}^{2+}$ ions means more opportunities contacts with a constant amount of the adsorbent.

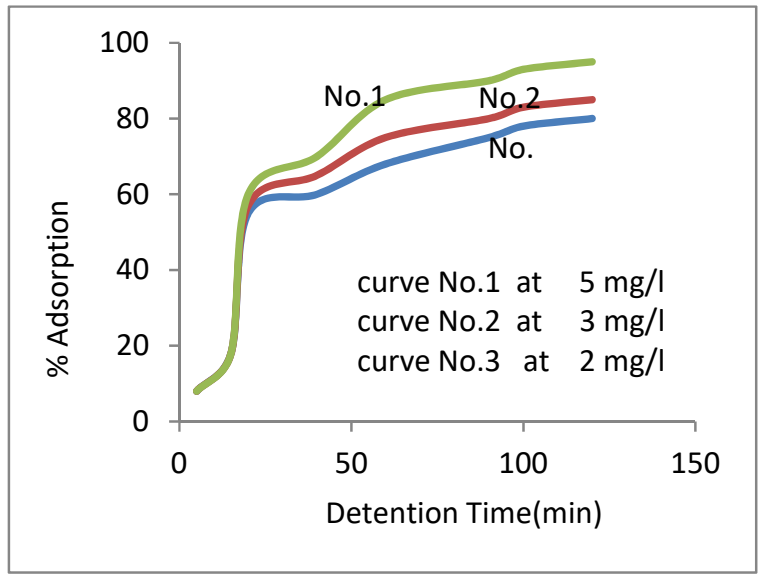

Fig. 3 Initial concentration of $\mathrm{Cu}^{+2}$ ions effect on the efficiency adsorption onto Cane Papyrus.

Curve No.1 represent to $5 \mathrm{mg} / 1$ of initial concentration, 120 minutes and $95 \% \mathrm{Cu}^{2+}$ ions removal. Curve No.2 represent to $3 \mathrm{mg} / \mathrm{l}$ of initial concentration, 120 minutes and $85 \% \mathrm{Cu}^{2+}$ ions removal. Curve No. 3 represent to $2 \mathrm{mg} / 1$ of initial concentration, 120 minutes and $80 \% \mathrm{Cu}^{2+}$ ions removal. The lines are not fitting functions, they simply connect points to facilitate visualization. It is expected that when the initial ion concentration is increased, the rate of adsorption would be increased. With reference to the limitation of the adsorption sites, increasing the initial $\mathrm{Cu}^{2+}$ concentration would reduce the ratio of $\mathrm{Cu}^{+2}$ which might be absorbed relative to the total amount of copper ions in the solution.

\subsection{Effect of Adsorbent Dosage}

Fig.4 represent changes of aqueous $\mathrm{Cu}^{2+}$ inos concentrations as a function of the time for an adsorbent mass loading of $50 \mathrm{~g} / \mathrm{l}$. It is seen that $\mathrm{Cu}^{2+}$ ions removal increased very sharply at the beginning reaching $50 \%$ after some 25 minutes. At 60 minutes, a plateau is reached at about $75 \% \mathrm{Cu}^{2+}$ ions removal and is maintained through the end of the experiment (120 minutes). Data from Fig. 5 suggest that 2 hours (120 minutes is suitable for the achievement of a pseudoequilibrium under the experimental conditions of this work. The effect of adsorbent mass loading varying from $10 \mathrm{~g} / 1$ to $50 \mathrm{gm} / 1$ on $\mathrm{Cu}^{2+}$ ions removal for 2 hours is summarized in Fig.5. The $\mathrm{Cu}^{2+}$ ions removal efficiencies were 78,82 , and $95 \%$ for 10,30 and $50 \mathrm{gm} / 1$ Cane Papyrus, at the conditions volume $1 \mathrm{~L}$ and $\left[\mathrm{Cu}^{+2}\right]$ concentration $=3 \mathrm{mg} / \mathrm{L}$. This plateau at the end of curves probably is from saturation of the surface of adsorbent with metal ions followed by adsorption and desorption processes that occur after saturation.

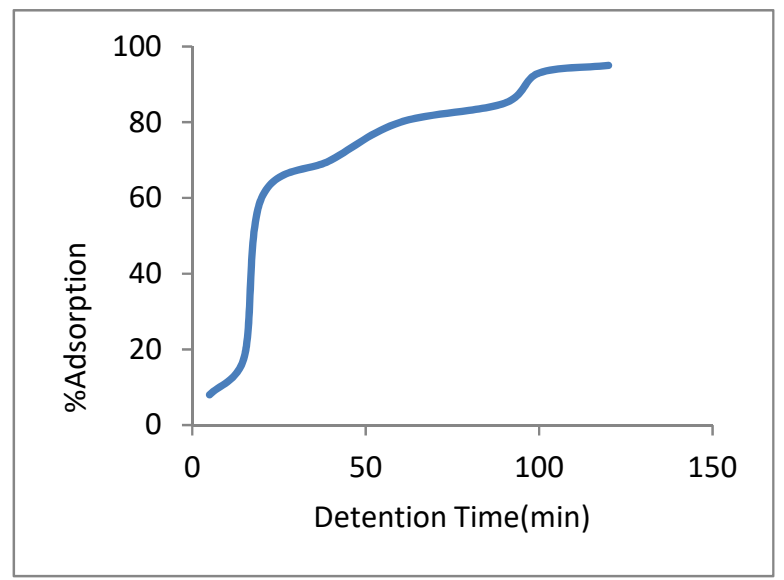

Fig. 4 Effect of Cane Papyrus Dosage on the adsorption efficiency of $\mathrm{Cu}^{+2}$ ions.

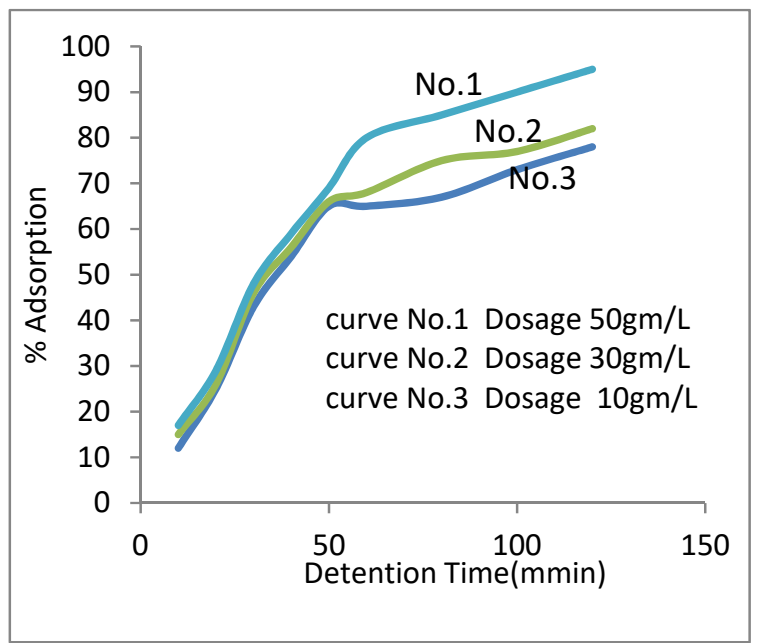

Fig. 5 Various Dosage of Cane Papyrus Effects on the $\mathrm{Cu}^{+2}$ ions adsorption efficiency.

\section{Adsorption Isotherms}

Experimental data for the adsorbed metal against initial concentration were fitted into the langmuir and Freundlich adsorption isotherms. The Langmuir model [14] assumes that the adsorption of an ideal gas on an ideal surface occurs only at fixed number of sites and each site can only hold one adsorbent molecule (monolayer). It also assumes that all available sites are equivalent and there is no interaction between adsorbed molecules on adjacent sites. The linearized equation for langmiur model [15] is represented by Equation (3).

$$
\frac{l}{\mathrm{qe}}=\frac{l}{\mathrm{qmax}}+\left\{\frac{l}{\mathrm{bqmax}}\right\} \frac{l}{\mathrm{Ce}}
$$

where $\mathrm{Ce}$ is the equilibrium concentration of the metal ion $(\mathrm{mg} / \mathrm{l}), \mathrm{q}_{\mathrm{e}}$ is the quantity of $\mathrm{Cu}^{+2}$ ions adsorbed at equilibrium $(\mathrm{mg} / \mathrm{g}), \mathrm{q}_{\max }$ is the maximum amount adsorbed $(\mathrm{mg} / \mathrm{g})$ and $\mathrm{b}$ is the adsorption constant $(\mathrm{l} / \mathrm{mg})$. 
The plot of $1 / \mathrm{q}_{\mathrm{e}}$ against $1 / \mathrm{Ce}$ gave a straight line with a regression coefficient of 0.8442 (Fig.6) indicating that the adsorption conforms to langmuir model. The maximum concentration of $\mathrm{Cu}^{+2}$ ions adsorbed and the adsorption capacity was calculated from the slope and intercept of the plot and are shown in Table 3 . The conformity of the adsorption process to langmuir model was determined using Equation (4).

$$
\mathrm{Rl}=\frac{l}{(1+\mathrm{bCo})}
$$

where $R_{1}$ is the separation factor, Co is the initial metal concentration $(\mathrm{mg} / \mathrm{l})$ and $\mathrm{b}$ is the langmuir constant $(1 / \mathrm{mg}) . \quad \mathrm{R}_{1}>1$ indicates an unfavorable monolayer adsorption process, $\mathrm{R}_{1}=1$ linear, $0<\mathrm{R}_{1}<1$ favorable and $\mathrm{R}_{1}=0$ irreversible. The result obtained from this study has an $R_{1}$ value between zero and one, indicating a favorable adsorption process. This implies that chemisorptions process duly explains the adsorption of $\mathrm{Cu}^{+2}$ ions onto Cane Papyrus.

Table 3: Freundlich and Langmuir constants for $\mathrm{Cu}^{+2}$ ions adsorption onto Cane Papyrus.
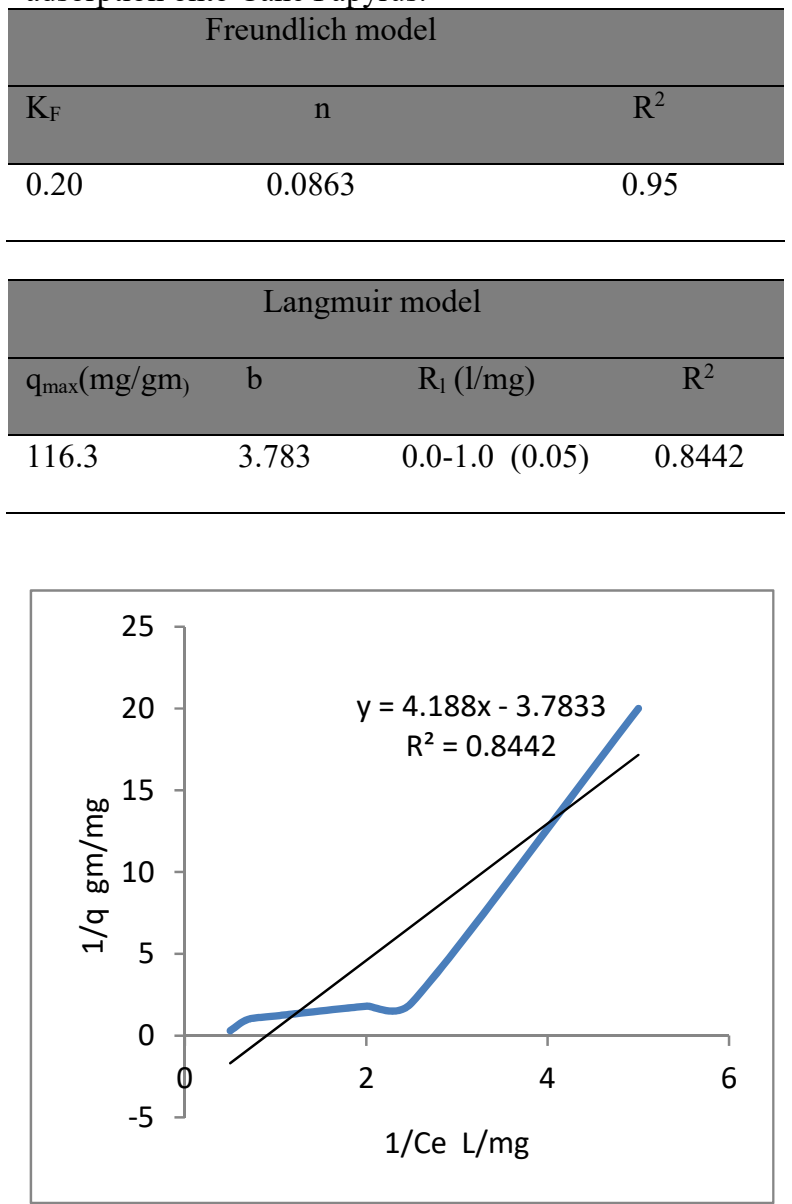

Fig. 6 Langmuir plot for $\mathrm{Cu}^{+2}$ ions adsorption onto Cane Papyrus.
The Freundlich isotherm mode[16] describes a multi-site adsorption for heterogeneous surfaces and can be represented by Equation (5).

$$
\mathrm{q}_{\mathrm{e}}=\mathrm{K}_{\mathrm{f}} \mathrm{Ce}^{1 / \mathrm{n}}
$$

where $K_{f}$ is the adsorption capacity $(1 / \mathrm{mg})$ and $1 / n$ is the intensity of the adsorption showing the heterogeneity of the adsorbent site and the energy of distribution. Equation (6) was obtained by taking the logarithm of Equation (5):

$$
\log \mathrm{q}_{\mathrm{e}}=\log \mathrm{K}_{\mathrm{l}}+\frac{l}{n} \log \mathrm{C}_{\mathrm{e}}
$$

A plot of logqe against $\log C e$ gave a linear graph with a regression coefficient of 0.95 (Fig.7), indicating that the adsorption also fits into Freundlich model. From the linearized coefficients obtained from both models, the langmuir model best described the adsorption process than the Freundlich model. This suggests a chemisorptions process rather than a physisorption process. The constants obtained for the Freundlich and langmuir plot is presented in Table 3. A maximum adsorption capacity of $116.3 \mathrm{mg} / \mathrm{g}$ was obtained in this study for the adsorption of $\mathrm{Cu}^{+2}$ ions. The use of Cane Papyrus is therefore a potential candidate for the removal of $\mathrm{Cu}^{+2}$ ions in water and wastewater.

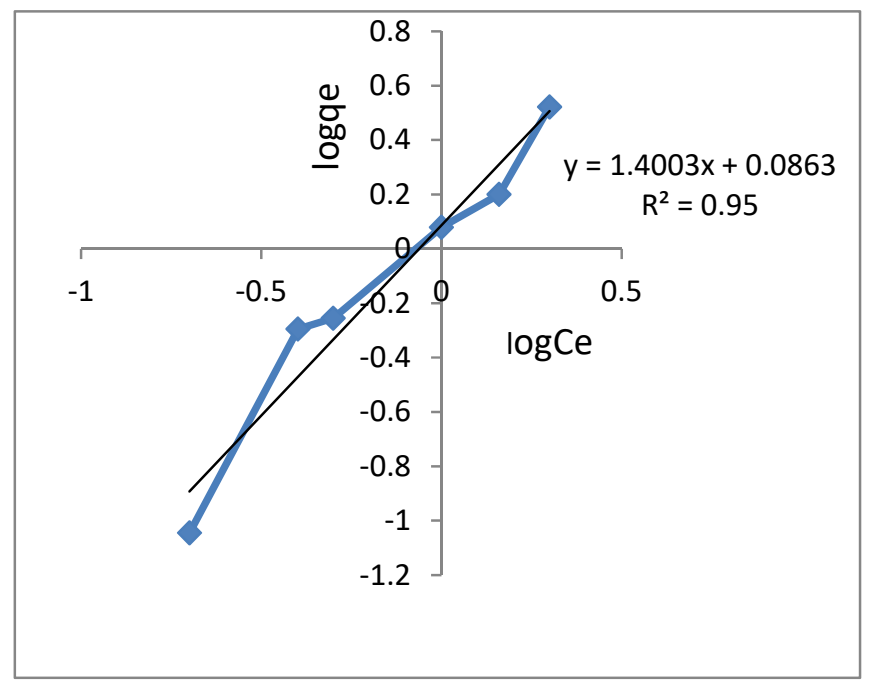

Fig. 7 Freundlich plot for $\mathrm{Cu}^{+2}$ ions adsorption onto Cane Papyrus.

\section{The Models of Adsorption Reaction}

The mechanism adsorption reactions are usually carried out using adsorption reaction models and adsorption diffusion models. Both models are used to understand the kinetics of the reaction. The linearized equations for the pseudo first and pseudo second order kinetics are presented in Equations (7) and (8), respectively.

$$
\log (q e-q t)=\log q e-\left\{\frac{K t}{2.303}\right\}
$$




$$
\frac{\mathrm{t}}{\mathrm{qt}}=\left\{\frac{1}{\mathrm{~K} 2 \mathrm{qe} 2}\right\}+\frac{1}{\mathrm{qe}}
$$

where $\mathrm{q}_{\mathrm{e}}$ and $\mathrm{q}_{\mathrm{t}}$ are the amounts of $\mathrm{Cu}^{+2}$ ions adsorbed at equilibrium and at a given time $\mathrm{t} ; \mathrm{k}_{1}$ and $\mathrm{k}_{2}$ are the rate constants of pseudo first and pseudo second order models. The pseudo first order kinetic model [17] was used to treat the experimental data obtained by plotting $\log \left(\mathrm{q}_{\mathrm{e}}-\mathrm{q}_{\mathrm{t}}\right)$ vs. equilibration time (Fig. 9). A linearity coefficient of 0.8261 was obtained. Similarly, a linear graph $\left(R_{2}=0.9508\right)$ was obtained by plotting $t / q_{t}$ values against time $t$ (Fig. 8). The pseudo second order best describes the kinetics of the adsorption process and this agrees with other results reported in the literature. The result obtained from the kinetic plot favors chemisorptions mechanistic pathway rather than physisorption.

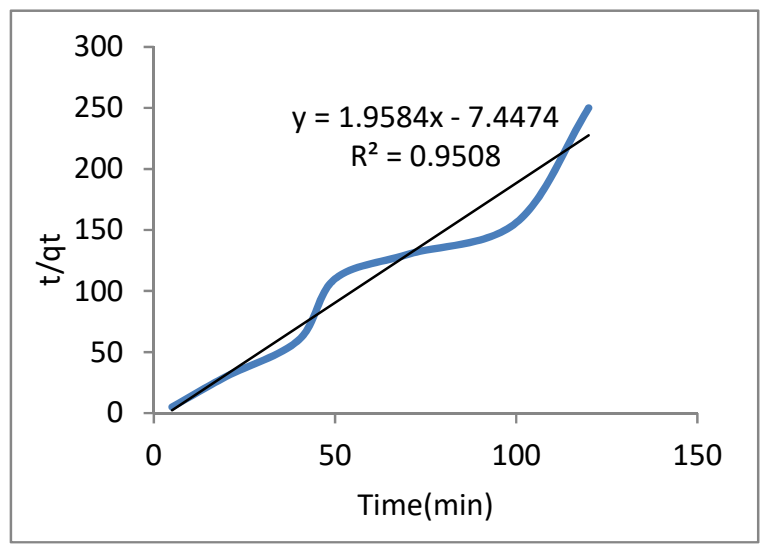

Fig. 8 Pseudo second order kinetics for $\mathrm{Cu}^{+2}$ ions adsorption onto Cane Papyrus.

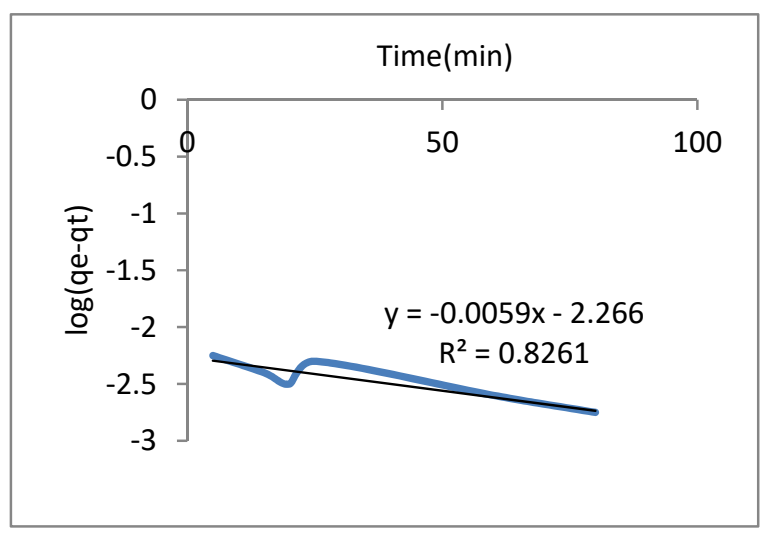

Fig. 9 Pseudo first order kinetics for $\mathrm{Cu}^{+2}$ ions adsorption onto Cane Papyrus.

Mechanism Based Model Weber-Morris mechanistic model in Equation 9 was used to ascertain whether intraparticle diffusion or film diffusion (external diffusion) is the rate-controlling step.

$\mathrm{qt}=\mathrm{Kd}(\mathrm{t})^{1 / 2}+\mathrm{I}$ where $\mathrm{k}_{\mathrm{d}}$ is the intra-particle diffusion rate constant $(\mathrm{mg} / \mathrm{g}$ $\left.\min ^{-0.5}\right)$ and $\mathrm{I}(\mathrm{mg} / \mathrm{g})$ is a constant describing the thickness of the boundary layer. A linear plot of qt versus $\mathrm{t}^{1 / 2}$ passing through the origin will suggest intra-particle diffusion as the sole rate-determining step. However, if a linear plot was obtained that is not passing through the origin, it means the adsorption process is controlled by more than one mechanism. In this study, a linear plot was obtained that did not pass through the origin (Fig.10), suggesting that the mechanism of the reaction is multilinear and the rate-limiting reaction is controlled both through film diffusion and intra-particle diffusion.

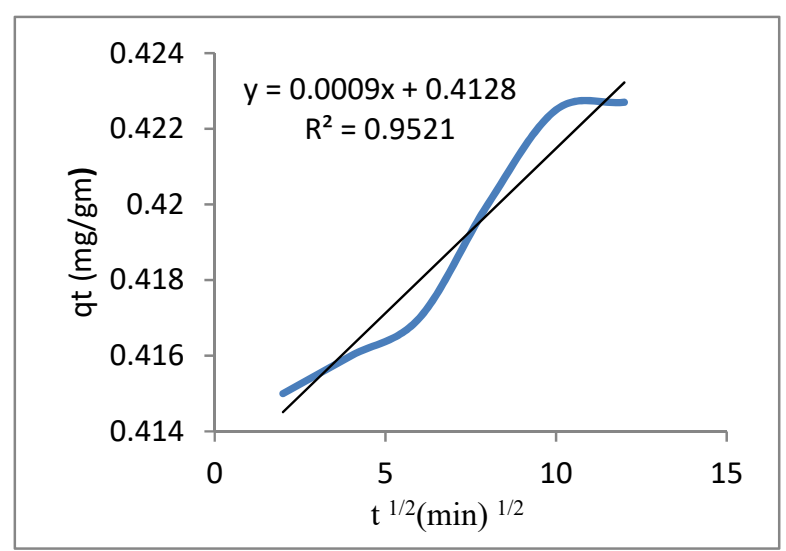

Fig. 10 Intra-particle diffusion model plot for $\mathrm{Cu}^{+2}$ ions adsorption onto Cane Papyrus.

\section{Desorption Studies}

This study was carried out to assess the most suitable desorbing agent for eluting adsorbed $\mathrm{Cu}^{+2}$ ions from the surface of Cane Papyrus. The effects of de-ionized water, $0.5 \mathrm{M} \mathrm{NaOH}$ and $0.5 \mathrm{M} \mathrm{HCl}$ solutions were tested for their ability to remove the adsorbed $\mathrm{Cu}^{+2}$ ions from the surface of the adsorbent. $\mathrm{HCl}$ was a better desorbing agent and was able to recover $50 \%$ of $\mathrm{Cu}^{+2}$ ions adsorbed to the surface of the adsorbent. $\mathrm{NaOH}$ and de-ionized water showed desorption efficiencies of $25 \%$ and $2 \%$, respectively. Desorption is beneficial for the separation and enrichment of $\mathrm{Cu}^{+2}$ ions as well as the regeneration of the adsorbent.

\section{Conclusions}

The adsorption ability of powdered Cane Papyrus has been investigated and found effective for the removal of $\mathrm{Cu}^{+2}$ ions from wastewater. Acidic functional groups present on the surface Sustainability of the adsorbent is believed to be responsible for the removal of $\mathrm{Cu}^{+2}$ ions from aqueous media. The Freundlich isotherm model gave a better description of the adsorption process than the langmuir isotherm model. Pseudo-second order kinetics best described the kinetics of the reaction while $0.5 \mathrm{M} \mathrm{HCl}$ was a better desorbing agent than $0.5 \mathrm{M}$ $\mathrm{NaOH}$ and de-ionized water. 
Abbreviations

AAS Atomic Absorption Spectrometer

Cf Final Concentration of Metal Ions(mg/l)

$\mathrm{Ci} \quad$ Initial Concentration of Metal Ions $(\mathrm{mg} / \mathrm{l})$

K2 Pseudo-Second-Order Adsorption Rate Constant in (g/ mg.min)

R Universal Gas Constant ( $\mathrm{J} / \mathrm{mol}$. oK $)$

W Adsorbent Weight

\section{References}

[1] Marais Barros, A. J., Prasad, S., Du arte Leite , V. and Gouveia Souza, A., The process of biosorption of heavy metals in bioreactors loaded with sanitary sewage sludge. Braz. J. Chem. Eng., Volume 23, (2006), pp.153-162.

[2] Donohue, J. Copper in Drinking-water, World Health Organization (2004).

[3] Mohammed Jaafer Ali Alatabe, " Crystallization in Phase Change Materials", International Journal of Scientific Research in Science, Engineering and Technology, Volume 4, (2018), pp. 93- 99.

[4] Kulkarni, S.J. and Kaware, J.P. Fixed bed removal of heavy metal - Areview. International Journal of Research, Volume 1, (2014), pp.2348-2368.

[5] Mohammed Jaafar Ali Al-atabe, Removal of lead Ions from Industrial waste water. Journal of Environmental Studies, Volume 9, (2012), pp.1-7.

[6] Ong, S., Seng, C. and Lim, P., Kinetics of adsorption of $\mathrm{Cu}$ (II) and $\mathrm{Cd}$ (II) from aqueous solution on rice husk and modified rice husk. Electronic J.Environ. Agric. Food Chem., (2007), pp.1764-177.
[7] Swaminathan, E., Nagappan, S., Rajangam, P., Dharmalingam S. Separation of $\mathrm{Ni}^{2+}, \mathrm{Cu}^{2+}$ and $\mathrm{Cr}^{6+}$ Metal Ions from Water by Complexation Micro Filtration Technique Using Synthetic Polymer Membranes. Progress in Nanotechnology and Nanomaterials, Volume 2 (2015), pp. 47-54.

[8] Veli, S. and Pekey, B. Removal of copper from aqueous solution by ion exchange resins. Fresen. Environ.Bull. Volume13,(2004),pp.244-250.

[9] Kratochvil, D. and Volesky, B. Advances in biosorption of heavy metals. Tren. in Biotechnol., Vol 16, (1998), pp. 291-300.

[10] Chen, H., Dai, G., Zhao, J., Zhong, A., Wu, J., Yan H. Removal of copper(II) ions by a biosorbentCinnamomum camphora leaves powder. J. Hazard. Mater. Volume 3, (2010), pp. 228-236.

[11] Pehlivan, E., Altun, T., Parlayici, Ş. Modified barley straw as a potential bio- sorbent for removal of copper ions from aqueous solution. Food Chem., Volume 4, (2012), pp. 2229-2234.

[12] Smith, B.C. Fundamentals of Fourier Transform Infrared Spectroscopy, Second Edition, Taylor and Francis Group (2011).

[13] Mohammed Jaafar Ali Al-atabe, Ahmed Alaa. Isotherm and Kinetics studies, Adsorption of Chromium(III)Ions from Wastewater Using Cane Papyrus. Themed Section: Engineering and Technology, Volume 3 (2017), pp.2394-4099.

[14] Langmuir I. The constitution and fundamental properties of solids and liquids. J Am Chem Soc. 38:(1916), pp. 2221-2295.

[15] Langmuir, I., The adsorption of gases on plane surfaces of glass, mica and platinum. J. Am. Chem. Soc.,40, (1918), pp.1361-1403.

[16] Freundlich HMF Over the adsorption in solution. J Phys Chem., 57:3, (1906), pp. 85-471.

[17] Ho, Y. S. and McKay, G., Pseudo- second-order model for sorption processes. Process Biochem., 34, (1999),pp.451-465. 